\section{Performance of Red Maple Selections in Southern Georgia}

\author{
John M. Ruter ${ }^{1}$ and \\ Jeff L. Sibley ${ }^{2}$
}

AdDitional INDEX WORds. cultivar, growth, foliage color, A cer rubrum

Summary. In 1991, a cooperative project with the $U$.S. $N$ ational Arboretum in Washington, D.C., was initiated in Tifton, Ga. (U SD A hardiness zone 8a) to evaluate red maples (A cer rubrum L.) potentially suitable for the coastal plain region of the southeastern U .S. G reatest annual height growth across all cultivars over 6 years was for 'Alapaha', a seedling selection from southern G eorgia with annual height growth of 35 inches $(88.0 \mathrm{~cm})$, and several seedling selections from northern Florida with annual height increases in excess of 33 inches $(86.0 \mathrm{~cm})$. Selections showing the least average annual height growth were N A-56024 and N A57772 ('Red R ocket'). For commercially available cultivars, the most dependable for fall color in T ifton was 'O ctober G lory' ${ }^{\circledR}$. In addition, two new selections from the $\mathrm{N}$ ational Arboretum have also shown excellent fall color- 'Somerset' and 'Brandywine'.

$\mathrm{R}$ ed maple (A cer rubrum) is a commonly used landscape tree throughout the eastern U nited States. There are many new or underused selections of red maple with landscape potential for urban and residential sites in the south-

Department of H orticulture, U niversity of Georgia, Tifton Campus, Tifton GA 31793-0748.

$M$ ention of a trademark or proprietary product does not imply endorsement of the products named or criticism of other products not named that may also be suitable. The cost of publishing thispaper was defrayed in part by the payment of page charges. U nder postal regulations, thispaper thereforemust behereby marked advertisement solely to indicate this fact.

${ }^{1}$ Associate professor.

${ }^{2}$ Former graduate student. Currently assistant professor, D epartment of $\mathrm{H}$ orticulture, Auburn U niversity AL 36849. eastern U nited States. Seedling red maples are often planted with expectations of rapid growth, attractivecanopy form, and excellent red fall color. However, studies have shown great variability among seedling red maples collected across their native range, extending throughout the eastern U.S. and $C$ anada (T ownsend, 1977). Seedling variability has been the major avenue for selection of new cultivars of red maple. The po pularity of red maple cultivars rests in their known uniformity with regard to a particular form, unique foliage, or fall color. Considerable variation exists among cultivars in their regional adaptability (Ruter, 1996; Williams et al., 1993; Witte et al., 1997). O f about 58 recognized red maplecultivars, few have been selected from provenances in thesouthern portion of the species native range. $D$ etermination of suitable red maple cultivars for the southeastern U.S. can increase the choices of reliable shadeand ornamental trees for landscape use (Ruter, 1996).

\section{Materials and methods}

Cultivars in these trials represent a broad cross section of the classified red maples (Santamour and M cArdle, 1982; Witte et al., 1997), including those known from previous studies to perform well in the southeastern U nited States (Fare et al., 1990; Sibley et al., 1995; Witte et al., 1997). N ew or pending releases from the U.S. $\mathrm{N}$ ational Arboretum were selected for their insect tolerance and the presence of several unique and desirable horticultural attributes (D ix, 1997). A selection from the freeman maple (A cer $x$ Freemanii $E$. Murray) group ['Jeffersred' ('Autumn Blaze' ${ }^{\circledR}$ )] was also included. A clonal seedling selection ('Alapaha') from southern Georgiawasincluded, along with individual seedling selections from southern Georgia and northern Florida.

Threetrees of each selection were planted beginning in J anuary, 1992 using container-grown trees of similar size, ranging from 4 to $5 \mathrm{ft}$ ( 1.2 to 1.5 $\mathrm{m}$ ) in height on their own roots supplied by the U.S. N ational Arboretum and several nursery sources. All trees were container-grown for a minimum of nine months under standard cultural conditions in T ifton before transplanting. Trees were field planted in full sun in Tifton loamy sand; fineloamy, siliceous, thermic Plinthic
Paleudult soil in Tifton [ $31^{\circ} 27^{\prime} \mathrm{N} \times$ 8331'W, elevation $357 \mathrm{ft}(109 \mathrm{~m})$ ], in U SDA hardiness zone 8a (U SDA, 1990); plant heat zone 8 [American H orticultural Society (ASH), 1997]. $M$ inimum and maximum daylengths in Tifton areabout 10 and $14 \mathrm{~h}$, respectively. T rees were planted on $10 \times 12.5$ $\mathrm{ft}(3.0 \times 3.8 \mathrm{~m})$ spacing and were fertilized with $50 \mathrm{lb} \mathrm{N} /$ acre $\left(56 \mathrm{~kg} \cdot \mathrm{ha}^{-1}\right)$ of $\mathrm{N}$ using $16 \mathrm{~N}-1.7 \mathrm{P}-6.6 \mathrm{~K}$ plus micronutrients at planting and in subsequent years every $M$ arch. A 5-ft ( 1.5 $\mathrm{m})$ wide band of composted pecan shell mulch was applied to a depth of 2 inches $(5 \mathrm{~cm})$ at planting and was replenished as needed. D rip irrigation was supplied to each tree during periods of extended drought. $\mathrm{H}$ eight (from soil line to tip of the uppermost bud) and stem diameter [at 12 inches (30 $\mathrm{cm}$ ) above soil line] measurementswere recorded at planting and annually thereafter through the 1998 growing season. G rowth increase was determined by subtracting the previous season's measurement from the current season's measurement. Foliar fall color was evaluated annually from two to three times weekly September through $D$ ecember, as described by Sibley et al. (1995). R esultsfrom evaluations of 21 cultivars or unnamed selections are presented in this report (Tables 1-2, Figs. 1-3).

\section{Results and discussion}

'Alapaha', a seedling selection from Berrien County, Ga., produced the greatest annual height growth across all cultivars over six years with annual height growth of about 34 inches $(87.2 \mathrm{~cm})$ (Table 1$)$. Three seedling selections from northern Florida $(\mathrm{OH}-2, \mathrm{OH}-3$, and $\mathrm{OH}-4)$ had annual height growth increases of about 34, 37, and 36 inches (86.3, 95.0 , and $90.8 \mathrm{~cm}$ ), respectively, over a 4-year period and another northern Florida selection $(\mathrm{OH}-6)$ had annual height increases of 36 inches $(90.3$ $\mathrm{cm}$ ) over a 3-year period (Table 1 ). The least height growth was 14 inches $(35.7 \mathrm{~cm})$ and 13 inches $(33.5 \mathrm{~cm})$, respectively, for NA-56024 and NA57772 ('Red Rocket') (Table 1).

The greatest stem diameter growth occurred for seedling selections $\mathrm{OH}-2, \mathrm{OH}-3$, and $\mathrm{OH}-4$ from northern Florida along with 'Alapaha' averaging 1.0 to 1.1 inch/ year (26.3 to $29 \mathrm{~mm} \cdot$ year $^{-1}$ ). $M$ any selectionswith poor height growth also had poor 
T able 1. Annual final height (inch) for red maple variety trials in Tifton, $G$ a., 1992-98.

\begin{tabular}{|c|c|c|c|c|c|c|c|c|}
\hline Selection & 1992 & 1993 & 1994 & 1995 & 1996 & 1997 & 1998 & $\begin{array}{c}\text { Avg ht } \\
\text { increase } \\
\text { 1992-98 }\end{array}$ \\
\hline Alapaha & $89 a b^{y}$ & $145 a b$ & $204 a$ & $213 a$ & $255 a$ & $281 \mathrm{a}$ & $295 a$ & $35 a b$ \\
\hline Autumn Blaze & $55 \mathrm{~cd}$ & $71 \mathrm{fg}$ & $122 \mathrm{~cd}$ & 146 efg & 167 def & $201 \mathrm{cde}$ & $232 \mathrm{bcd}$ & 30 cde \\
\hline Autumn Flame & $63 \mathrm{~cd}$ & $87 \mathrm{~d}-\mathrm{g}$ & $138 \mathrm{bcd}$ & $169 c-f$ & $201 \mathrm{c}$ & $220 b c$ & $234 \mathrm{bcd}$ & 29 def \\
\hline Edna $D$ avis & $65 \mathrm{~cd}$ & 91 def & $134 \mathrm{bcd}$ & $152 d-g$ & 173 def & $197 \mathrm{c}-\mathrm{f}$ & $234 \mathrm{bcd}$ & 28 def \\
\hline N A -55410 & $47 \mathrm{de}$ & 77 efg & $112 \mathrm{~d}$ & $139 \mathrm{~g}$ & $157 \mathrm{f}$ & $169 \mathrm{f}$ & --. & $25 \mathrm{e}-\mathrm{h}$ \\
\hline N A-56021 (Cumberland) & $58 \mathrm{~cd}$ & 100 cde & $131 \mathrm{bcd}$ & $141 \mathrm{fg}$ & $159 \mathrm{f}$ & 181 ef & $215 d$ & 28 def \\
\hline N A-56024 & $64 \mathrm{~cd}$ & $64 \mathrm{~g}$ & $87 \mathrm{e}$ & $102 \mathrm{~h}$ & $123 \mathrm{~g}$ & $135 \mathrm{~g}$ & $125 \mathrm{e}$ & $14 \mathrm{i}$ \\
\hline N A-57772 (Red Rocket) & $30 \mathrm{e}$ & $38 \mathrm{~h}$ & $68 \mathrm{e}$ & $83 \mathrm{~h}$ & $91 \mathrm{~h}$ & $96 \mathrm{~h}$ & -- & $13 \mathrm{i}$ \\
\hline NA-57775 & $54 \mathrm{~cd}$ & $74 \mathrm{fg}$ & $119 \mathrm{~cd}$ & $139 \mathrm{~g}$ & 161 ef & 189 def & $217 d$ & $27 d-g$ \\
\hline N A-59905 (Somerset) & $67 \mathrm{~cd}$ & 79 efg & $125 \mathrm{~cd}$ & 145 efg & 166 def & 190 def & $203 d$ & $23 \mathrm{gh}$ \\
\hline N A-59906 (Sun Valley) & $69 \mathrm{bc}$ & 101 cde & $141 b c$ & $152 \mathrm{~d}-\mathrm{g}$ & 169 def & 179 ef & $205 d$ & $21 \mathrm{~h}$ \\
\hline N A-59907 (Brandywine) & $75 a b c$ & $106 \mathrm{~cd}$ & $146 \mathrm{bc}$ & $157 d-g$ & $181 \mathrm{cde}$ & $213 \mathrm{~cd}$ & $224 \mathrm{~cd}$ & $25 \mathrm{e}-\mathrm{h}$ \\
\hline NA-60068 & $66 \mathrm{~cd}$ & $83 d-g$ & $127 \mathrm{bcd}$ & $141 \mathrm{fg}$ & 165 def & $197 c-f$ & $208 d$ & $24 \mathrm{fgh}$ \\
\hline N A-61016 & $62 \mathrm{~cd}$ & 103 cde & $153 \mathrm{~b}$ & $190 a b c$ & $201 \mathrm{c}$ & $224 b c$ & $252 b c$ & $31 \mathrm{bcd}$ \\
\hline $\mathrm{OH}-1$ & $87 a b$ & $134 a b$ & $195 a$ & $201 a b$ & $220 \mathrm{~b}$ & $244 b$ & $259 \mathrm{~b}$ & 29 def \\
\hline $\mathrm{OH}-2$ & $89 a b$ & $148 a b$ & $197 \mathrm{a}$ & $209 a$ & $224 \mathrm{~b}$ & --- & --- & $34 a b c$ \\
\hline $\mathrm{OH}-3$ & $75 a b c$ & $130 \mathrm{bc}$ & $183 a$ & $193 a b c$ & $224 \mathrm{~b}$ & --- & --- & $37 a$ \\
\hline $\mathrm{OH}-4$ & $93 a$ & $154 a$ & $193 a$ & $207 a$ & $236 \mathrm{~b}$ & --- & --- & $36 a b$ \\
\hline $\mathrm{OH}-6$ & $--{ }^{x}$ & $31 \mathrm{~h}$ & $69 \mathrm{e}$ & $128 \mathrm{~g}$ & $138 \mathrm{~g}$ & $\cdots$ & -- & $36 \mathrm{ab}$ \\
\hline O ctober G lory & $71 b c$ & $106 \mathrm{~cd}$ & $154 \mathrm{~b}$ & 173 cde & 181 cde & $217 \mathrm{bcd}$ & $234 \mathrm{bcd}$ & $27 d-g$ \\
\hline Red Sunset & $73 b c$ & 102 cde & $137 \mathrm{bcd}$ & $175 \mathrm{bcd}$ & $182 \mathrm{~cd}$ & $213 \mathrm{~cd}$ & $230 \mathrm{bcd}$ & $25 e-h$ \\
\hline
\end{tabular}

zSelection accession number, followed by cultivar name if available.

yM ean separation by D uncans' multiple range test. $\mathrm{M}$ eans followed by the same letter are considered not different at $\mathrm{P}=0.05$.

${ }^{\times} \mathrm{M}$ issing data due to late planting dates or attrition.

T able 2. Annual final stem diameter (inch) for red maple variety trials in Tifton, $G$ a., 1992-98.

\begin{tabular}{|c|c|c|c|c|c|c|c|c|}
\hline Selection $^{2}$ & 1992 & 1993 & 1994 & 1995 & 1996 & 1997 & 1998 & $\begin{array}{c}\text { Avg diam } \\
\text { increase } \\
\text { 1992-98 } \\
\end{array}$ \\
\hline Alapaha & $1.3 a b c^{y}$ & $2.5 \mathrm{bc}$ & $4.1 \mathrm{ab}$ & $5.3 \mathrm{a}$ & $5.9 a$ & $7.1 \mathrm{a}$ & $7.4 a$ & $1.01 \mathrm{a}$ \\
\hline Autumn Blaze & $0.5 \mathrm{gh}$ & $1.2 \mathrm{~h}$ & $2.3 \mathrm{fgh}$ & 3.3 def & $3.7 \mathrm{def}$ & $4.6 \mathrm{cde}$ & $5.4 \mathrm{bcd}$ & $0.81 b c$ \\
\hline Autumn Flame & $1.2 \mathrm{bcd}$ & 1.9 def & $3.0 \mathrm{de}$ & 3.5 cde & $3.9 \mathrm{~cd}$ & $4.4 \mathrm{cde}$ & $5.1 \mathrm{~b}-\mathrm{e}$ & $0.65 b-f$ \\
\hline Edna D avis & $0.9 \mathrm{e}$ & $1.7 \mathrm{fg}$ & $2.8 \mathrm{def}$ & $3.5 \mathrm{~cd}$ & $4.2 \mathrm{~cd}$ & $5.0 \mathrm{bc}$ & $5.7 \mathrm{bc}$ & $0.80 \mathrm{bcd}$ \\
\hline N A-55410 & 0.7 efg & $1.1 \mathrm{hi}$ & $1.7 \mathrm{hi}$ & $2.2 \mathrm{gh}$ & $2.4 \mathrm{~h}$ & $2.8 \mathrm{fg}$ & -- & $0.42 \mathrm{gh}$ \\
\hline N A-56021 (Cumberland) & $0.8 \mathrm{e}$ & $1.5 \mathrm{gh}$ & $2.3 \mathrm{fgh}$ & $2.8 \mathrm{~d}-\mathrm{g}$ & $3.2 \mathrm{fg}$ & $3.7 \mathrm{def}$ & $4.0 \mathrm{def}$ & $0.54 \mathrm{fgh}$ \\
\hline N A-56024 & $0.6 \mathrm{fg}$ & $0.8 \mathrm{ij}$ & $1.4 \mathrm{ij}$ & $1.8 \mathrm{hi}$ & $2.1 \mathrm{~h}$ & $2.5 \mathrm{~g}$ & $2.9 \mathrm{f}$ & $0.37 \mathrm{~h}$ \\
\hline N A-57772 (Red Rocket) & $0.4 \mathrm{~h}$ & $0.5 \mathrm{j}$ & $0.9 \mathrm{j}$ & $1.2 \mathrm{i}$ & $1.4 \mathrm{i}$ & $1.4 \mathrm{~h}$ & --- & $0.21 \mathrm{i}$ \\
\hline N A-57775 & $0.8 \mathrm{ef}$ & $1.3 \mathrm{gh}$ & $2.2 \mathrm{fgh}$ & 2.7 efg & $3.1 \mathrm{~g}$ & $3.8 \mathrm{def}$ & 4.1 def & $0.55 \mathrm{fgh}$ \\
\hline N A-59905 (Somerset) & 0.7 efg & $1.2 \mathrm{~h}$ & $2.3 \mathrm{fgh}$ & $2.8 \mathrm{~d}-\mathrm{g}$ & 3.4 efg & $4.1 \mathrm{cde}$ & 4.4 cde & 0.63 def \\
\hline N A-59906 (Sun Valley) & $1.1 \mathrm{~cd}$ & 1.9 def & $3.0 \mathrm{de}$ & 3.5 cde & 3.7 def & $4.5 \mathrm{cde}$ & 4.5 cde & $0.57 \mathrm{fg}$ \\
\hline N A-59907 (Brandywine) & $1.2 \mathrm{bcd}$ & $2.2 \mathrm{~cd}$ & $3.3 d$ & $3.6 \mathrm{~cd}$ & $4.0 \mathrm{~cd}$ & 4.2 cde & $4.7 \mathrm{~b}-\mathrm{e}$ & 0.61 ef \\
\hline N A-60068 & $0.7 \mathrm{ef}$ & $1.2 \mathrm{~h}$ & $2.2 \mathrm{gh}$ & 2.7 efg & $3.1 \mathrm{~g}$ & 3.5 efg & $3.9 \mathrm{ef}$ & $0.54 \mathrm{fgh}$ \\
\hline N A-61016 & $1.1 \mathrm{~cd}$ & $2.2 \mathrm{~cd}$ & $3.4 \mathrm{~cd}$ & $4.2 b c$ & $4.3 \mathrm{C}$ & $4.8 \mathrm{bcd}$ & $5.3 \mathrm{bcd}$ & $0.70 b-f$ \\
\hline $\mathrm{OH}-1$ & $1.3 \mathrm{a}-\mathrm{d}$ & $2.4 b c$ & $3.9 b c$ & $4.3 \mathrm{~b}$ & $4.8 \mathrm{~b}$ & $5.7 \mathrm{~b}$ & $5.9 \mathrm{~b}$ & $0.78 b-e$ \\
\hline $\mathrm{OH}-2$ & $1.4 \mathrm{a}$ & $2.7 a b$ & $4.1 \mathrm{ab}$ & $4.8 \mathrm{ab}$ & 5.9 & -- & $\cdots$ & $1.14 \mathrm{a}$ \\
\hline $\mathrm{OH}-3$ & $1.1 \mathrm{~cd}$ & $2.3 \mathrm{~cd}$ & $4.1 \mathrm{ab}$ & $4.6 \mathrm{ab}$ & $5.6 \mathrm{a}$ & -- & -- & $1.10 \mathrm{a}$ \\
\hline $\mathrm{OH}-4$ & $1.4 \mathrm{a}$ & $3.0 \mathrm{a}$ & $4.6 \mathrm{a}$ & $5.2 \mathrm{a}$ & $5.8 \mathrm{a}$ & -- & $\cdots$ & $1.09 \mathrm{a}$ \\
\hline $\mathrm{OH}-6$ & $--^{x}$ & $0.5 \mathrm{j}$ & $1.3 \mathrm{ij}$ & $2.6 \mathrm{fg}$ & $3.0 \mathrm{~g}$ & -- & -- & $0.83 \mathrm{~b}$ \\
\hline O ctober G lory & $1.1 \mathrm{~cd}$ & $2.1 \mathrm{cde}$ & $3.2 \mathrm{~d}$ & 3.5 cde & 3.8 cde & $4.5 \mathrm{cde}$ & $5.0 \mathrm{~b}-\mathrm{e}$ & $0.64 c-f$ \\
\hline Red Sunset & $1.1 \mathrm{~cd}$ & 1.7 efg & 2.4 efg & 3.1 def & $3.2 \mathrm{fg}$ & $4.3 \mathrm{cde}$ & 4.4 cde & $0.55 \mathrm{fgh}$ \\
\hline
\end{tabular}

"Selection accession number, followed by cultivar name if available

yM ean separation by D uncans' multiple range test. $M$ eans followed by the same letter are considered not different at $P=0.05$.

${ }^{x} \mathrm{M}$ issing data due to late planting dates or attrition. 
stem diameter increase. The least stem diameter growth occurred for NA57772 ('Red Rocket') with just over 0.2 inches $(5.3 \mathrm{~mm})$ per year diameter increase.

This evaluation demonstrates the importance of using germplasm from a provenance appropriatefor agiven geographical area and theneed to select red maple cultivars specifically adapted for use in U SD A zone 8 of the southeastern U.S. With the exception of N A-56021 ('Cumberland'), the $\mathrm{N}$ ational Arboretum selections in this study were from northern $M$ innesota in USDA hardi- ness zone $3 a$ or $3 b$ (Townsend and D ouglass, 1998), R hinelander, WI (N A55410) or are crosses between 'Franksred' ('Red Sunset'TM), 'O ctober Glory' ${ }^{\circledR}$ and 'Autumn Flame'.

Studies in Alabama and Tennessee found freeman maple selections 'Autumn Blaze' ${ }^{\circledR}$, 'Scarsen', and 'M organ' ('Indian Summer', 'E mbers') generally increased the most in height in trials. This precocity for height growth is typical of the silver maple parent (Bachtel, 1989; Santamour, 1993). 'Autumn Blaze' ${ }^{\circledR}$ in our trial evaluation, while not showing the same growth rates as reported in Alabama (Sibley et al., 1995) and Tennessee (Witte et al., 1997), appears to be well adapted to growing conditions in the coastal plain of Georgia. Growth differences for this evaluation compared to other studies may be attributed to environmental conditionssuch as photoperiod (Downs and Borthwick, 1956), chilling (Perry and Wang, 1960), rainfall, variable temperatures, or cultural practices (Perry, 1971). Furthermore, some caution must be used in comparing our own-root trees versus budded trees from other stud-

Fig. 1. H ue and duration of foliar fall color for red maple selections in 1995.

\begin{tabular}{|c|c|c|c|}
\hline Selection $^{2}$ & $\begin{array}{l}\text { Typical } \\
\text { color }^{y}\end{array}$ & $\begin{array}{l}\text { Color } \\
\text { present }\end{array}$ & $\begin{array}{l}\text { Peak } \\
\text { color }\end{array}$ \\
\hline NA-55410 & OR & $\begin{array}{l}23 \mathrm{O} \text { ct. to } 4 \mathrm{~N} \mathrm{ov} \text {. } \\
13 \text { to } 21 \mathrm{Nov} \text {. }\end{array}$ & 5 to $13 \mathrm{~N} \mathrm{ov}$. \\
\hline NA-56021 & $\mathrm{RP}$ & $23 \mathrm{Oct}$. to $13 \mathrm{Nov}$. & 14 to $20 \mathrm{~N} \mathrm{ov}$. \\
\hline NA-56024 & RO & $\begin{array}{l}27 \mathrm{O} \text { ct. to } 13 \mathrm{~N} \mathrm{ov} \text {. } \\
16 \text { to } 20 \mathrm{~N} \mathrm{ov} \text {. }\end{array}$ & 14 to $16 \mathrm{~N} \mathrm{ov}$. \\
\hline NA-57772 & OY & $\begin{array}{l}230 \mathrm{ct} . \text { to } 6 \mathrm{~N} \mathrm{ov} \text {. } \\
12 \text { to } 16 \mathrm{~N} \mathrm{ov} \text {. }\end{array}$ & 6 to $12 \mathrm{~N} \mathrm{ov}$. \\
\hline NA-57775 & $O B$ & 23 to $270 \mathrm{ct}$. & $27 \mathrm{Oct}$. to $9 \mathrm{Nov}$. \\
\hline NA-59905 & PR & $\begin{array}{l}270 \mathrm{ct} \text {. to } 10 \mathrm{~N} \mathrm{ov} \text {. } \\
25 \text { to } 30 \mathrm{~N} \mathrm{ov} \text {. }\end{array}$ & 11 to $24 \mathrm{Nov}$. \\
\hline NA-59906 & $\mathrm{R}$ & $\begin{array}{l}23 \mathrm{O} \text { ct. to } 6 \mathrm{~N} \mathrm{ov} \text {. } \\
13 \text { to } 20 \mathrm{~N} \mathrm{ov} \text {. }\end{array}$ & 6 to $13 \mathrm{~N} \mathrm{ov}$. \\
\hline NA-59907 & $\mathrm{RP}$ & $\begin{array}{l}23 \text { to } 29 \mathrm{Oct} \text {. } \\
13 \text { to } 30 \mathrm{~N} \mathrm{ov} \text {. }\end{array}$ & $29 \mathrm{Oct}$. to $12 \mathrm{~N} \mathrm{ov}$. \\
\hline NA-60068 & PR & $\begin{array}{l}270 \mathrm{ct} \text {. to } 17 \mathrm{~N} \mathrm{ov} \text {. } \\
26 \text { to } 30 \mathrm{~N} \mathrm{ov} \text {. }\end{array}$ & 17 to $25 \mathrm{~N} \mathrm{ov}$. \\
\hline NA-61016 & PR & $\begin{array}{l}270 \mathrm{ct} \text {. to } 11 \mathrm{Nov} \text {. } \\
25 \text { to } 30 \mathrm{~N} \mathrm{ov} \text {. }\end{array}$ & 11 to $25 \mathrm{~N} \mathrm{ov}$. \\
\hline Alapaha & YB & $\begin{array}{l}17 \mathrm{~N} \text { ov. to } 3 \mathrm{Dec} \text {. } \\
7 \text { to } 16 \mathrm{Dec} \text {. }\end{array}$ & 3 to $6 \mathrm{Dec}$. \\
\hline Autumn Blaze & RO & $\begin{array}{l}270 \mathrm{ct} \text { to } 15 \mathrm{~N} \mathrm{ov} \text {. } \\
24 \text { to } 30 \mathrm{~N} \mathrm{ov} \text {. }\end{array}$ & 16 to $24 \mathrm{~N} \mathrm{ov}$. \\
\hline Autumn Flame & ORY & $\begin{array}{l}27 \mathrm{O} \text { ct. to } 20 \mathrm{~N} \mathrm{ov} \text {. } \\
26 \text { to } 30 \mathrm{~N} \mathrm{ov} \text {. }\end{array}$ & 20 to $26 \mathrm{~N} \mathrm{ov}$. \\
\hline Edna Davis & RO & $\begin{array}{l}230 \mathrm{ct} \text {. to } 3 \mathrm{~N} \mathrm{ov} \text {. } \\
17 \text { to } 24 \mathrm{~N} \mathrm{ov} \text {. }\end{array}$ & 3 to $16 \mathrm{~N} \mathrm{ov}$. \\
\hline O ctober Glory & PR & $\begin{array}{l}270 \mathrm{ct} \text {. to } 17 \mathrm{Nov} \text {. } \\
1 \text { to } 2 \mathrm{Dec} \text {. }\end{array}$ & 17 to $30 \mathrm{~N} \mathrm{ov}$. \\
\hline Red Sunset & PRO & $\begin{array}{l}270 \text { ct. to } 20 \mathrm{~N} \text { ov. } \\
22 \text { to } 30 \mathrm{~N} \mathrm{ov} \text {. }\end{array}$ & 20 to $22 \mathrm{~N} \mathrm{ov}$. \\
\hline $\mathrm{OH}-1$ & $\mathrm{RP}$ & $\begin{array}{l}270 \mathrm{ct} \text {. to } 24 \mathrm{Nov} \text {. } \\
1 \text { to } 7 \mathrm{Dec} \text {. }\end{array}$ & 24 to $30 \mathrm{~N} \mathrm{ov}$. \\
\hline $\mathrm{OH}-2$ & YO & $\begin{array}{l}270 \mathrm{ct} \text {. to } 7 \mathrm{Dec} \text {. } \\
11 \text { to } 18 \mathrm{Dec} \text {. }\end{array}$ & 7 to $10 \mathrm{Dec}$. \\
\hline $\mathrm{OH}-3$ & PR & $\begin{array}{l}6 \text { to } 18 \mathrm{~N} \mathrm{ov} \text {. } \\
26 \mathrm{~N} \mathrm{ov} \text {. to } 7 \mathrm{Dec} \text {. }\end{array}$ & 17 to $25 \mathrm{~N} \mathrm{ov}$. \\
\hline $\mathrm{OH}-4$ & $\mathrm{R}$ & $\begin{array}{l}6 \mathrm{~N} \mathrm{ov} \text {. to } 8 \mathrm{Dec} \text {. } \\
10 \text { to } 18 \mathrm{Dec} \text {. }\end{array}$ & 7 to $10 \mathrm{Dec}$. \\
\hline $\mathrm{OH}-6$ & ORB & $\begin{array}{l}11 \text { to } 20 \mathrm{Nov} \text {. } \\
1 \text { to } 7 \mathrm{Dec} \text {. }\end{array}$ & 20 to $30 \mathrm{~N} \mathrm{ov}$. \\
\hline
\end{tabular}

"Cultivar names corresponding to NA accession numbers if available are NA-56021 ('Cumberland'); NA-59905 ('Somerset'); NA-59906 ('Sun Valley'); NA-59907 ('Brandywine'); and NA-57772 ('Red Rocket').

${ }^{y}$ Color notation as follows: $B=$ brown, $\mathrm{O}=$ orange, $\mathrm{P}=$ purple, $\mathrm{R}=$ red, $\mathrm{Y}=$ yellow (primary color listed first). 
Fig. 2. H ue and duration of foliar fall color for red maple selections in 1996.

\begin{tabular}{|c|c|c|c|}
\hline Selection ${ }^{2}$ & $\begin{array}{l}\text { Typical } \\
\text { color }^{y}\end{array}$ & $\begin{array}{l}\text { Color } \\
\text { present }\end{array}$ & $\begin{array}{l}\text { Peak } \\
\text { color }\end{array}$ \\
\hline N A-55410 & RPO & 40 ct. to $12 \mathrm{~N} \mathrm{ov}$. & 12 to $23 \mathrm{~N} \mathrm{ov}$. \\
\hline NA-56021 & RPO & $9 \mathrm{Oct}$. to $17 \mathrm{~N}$ ov. & 17 to $23 \mathrm{~N} \mathrm{ov}$. \\
\hline N A-56024 & RO & $4 \mathrm{Oct}$. to $12 \mathrm{~N} \mathrm{ov}$. & 12 to $23 \mathrm{~N} \mathrm{ov}$. \\
\hline NA-57772 & ROY & 4 to $300 \mathrm{ct}$. & $30 \mathrm{Oct}$. to $18 \mathrm{~N} \mathrm{ov}$. \\
\hline NA-57775 & RPO & $9 \mathrm{Oct}$. to $16 \mathrm{~N}$ ov. & 16 to $23 \mathrm{~N} \mathrm{ov}$. \\
\hline NA-59905 & RPO & $4 \mathrm{Oct}$. to $16 \mathrm{~N} \mathrm{ov}$. & 16 to $23 \mathrm{~N} \mathrm{ov}$. \\
\hline NA-59906 & RPO & $9 \mathrm{Oct}$ to $12 \mathrm{~N}$ ov. & 12 to $23 \mathrm{~N} \mathrm{ov}$. \\
\hline NA-59907 & RP & $17 \mathrm{Oct}$. to $24 \mathrm{~N} \mathrm{ov}$. & $24 \mathrm{~N} \mathrm{ov}$ to $2 \mathrm{Dec}$. \\
\hline NA-60068 & RPOY & $\begin{array}{l}4 \mathrm{O} \text { ct. to } 19 \mathrm{~N} \mathrm{ov} \text {. } \\
25 \mathrm{~N} \mathrm{ov} \text {. to } 6 \mathrm{Dec} \text {. }\end{array}$ & 19 to $25 \mathrm{Nov}$. \\
\hline NA-61016 & RPO & $9 \mathrm{Oct}$. to $19 \mathrm{~N} \mathrm{ov}$. & 19 to $25 \mathrm{~N} \mathrm{ov}$. \\
\hline Alapaha & YB & $12 \mathrm{~N}$ ov. to $7 \mathrm{Dec}$. & 7 to $13 \mathrm{D} \mathrm{ec}$. \\
\hline Autumn Blaze & RPO & $15 \mathrm{Oct}$. to $16 \mathrm{~N} \mathrm{ov}$. & 16 to $23 \mathrm{~N} \mathrm{ov}$. \\
\hline Autumn Flame & ORY & $9 \mathrm{Oct}$. to $20 \mathrm{~N} \mathrm{ov}$. & 20 to $23 \mathrm{~N} \mathrm{ov}$. \\
\hline Edna $D$ avis & RPO & $4 \mathrm{Oct}$. to $16 \mathrm{~N} \mathrm{ov}$. & 16 to $23 \mathrm{~N} \mathrm{ov}$. \\
\hline O ctober G lory & RP & $120 \mathrm{ct}$. to $20 \mathrm{~N} \mathrm{ov}$. & $20 \mathrm{~N}$ ov. to $2 \mathrm{Dec}$. \\
\hline Red Sunset & OYR & $9 \mathrm{Oct}$. to $20 \mathrm{~N} \mathrm{ov}$. & 20 to $23 \mathrm{~N} \mathrm{ov}$. \\
\hline $\mathrm{OH}-1$ & $\mathrm{RP}$ & $\begin{array}{l}12 \mathrm{Oct} \text {. to } 18 \mathrm{~N} \mathrm{ov} \text {. } \\
25 \mathrm{~N} \mathrm{ov} \text {. to } 4 \mathrm{D} \mathrm{ec} \text {. }\end{array}$ & 18 to $25 \mathrm{~N} \mathrm{ov}$. \\
\hline $\mathrm{OH}-2$ & ORY & 18 oct. to $9 \mathrm{Dec}$. & 9 to $16 \mathrm{Dec}$. \\
\hline $\mathrm{OH}-3$ & ROY & $4 \mathrm{Oct}$. to $2 \mathrm{Dec}$. & 2 to $6 \mathrm{Dec}$. \\
\hline $\mathrm{OH}-4$ & RP & $18 \mathrm{Oct}$. to $2 \mathrm{D} \mathrm{ec}$. & 2 to $16 \mathrm{D} \mathrm{ec}$. \\
\hline $\mathrm{OH}-6$ & RPYO & $12 \mathrm{Oct}$. to $21 \mathrm{~N} \mathrm{ov}$. & 21 to $28 \mathrm{Nov}$. \\
\hline & & $28 \mathrm{~N}$ ov. to $3 \mathrm{Dec}$. & \\
\hline
\end{tabular}

${ }^{2}$ Cultivar names corresponding to NA accession numbers if available are NA-56021 ('Cumberland'); NA-59905 ('Somerset'); NA-59906 ('Sun Valley'); NA-59907 ('Brandywine'); and NA-57772 ('Red Rocket').

${ }^{y}$ Color notation as follows: $B=$ brown, $O=$ orange, $P=$ purple, $R=$ red, $Y=$ yellow (primary color listed first).

Fig. 3. H ue and duration of foliar fall color for red maple selections in 1997.

\begin{tabular}{|c|c|c|c|}
\hline Selection $^{2}$ & $\begin{array}{c}\text { Typical } \\
\text { color }^{y}\end{array}$ & $\begin{array}{l}\text { Color } \\
\text { present }\end{array}$ & $\begin{array}{l}\text { Peak } \\
\text { color }\end{array}$ \\
\hline N A-55410 & ROP & $27 \mathrm{Oct}$. to $11 \mathrm{Nov}$. & 11 to $17 \mathrm{Nov}$. \\
\hline NA-56021 & RP & 300 ct. to $11 \mathrm{Nov}$. & 11 to $20 \mathrm{~N} \mathrm{ov}$. \\
\hline NA-56024 & ROY & $27 \mathrm{Oct}$. to $6 \mathrm{~N} \mathrm{ov}$. & 6 to $12 \mathrm{~N} \mathrm{ov}$. \\
\hline N A-57772 & ROY & 270 ct. to $6 \mathrm{~N} \mathrm{ov}$. & 6 to $9 \mathrm{Nov}$. \\
\hline N A -57775 & RPOY & $27 \mathrm{Oct}$. to $11 \mathrm{Nov}$. & 11 to $13 \mathrm{Nov}$. \\
\hline N A-59905 & $P R$ & $27 \mathrm{O}$ ct. to $13 \mathrm{Nov}$. & 13 to $26 \mathrm{~N} \mathrm{ov}$. \\
\hline NA-59906 & RPO & $27 \mathrm{Oct}$. to $5 \mathrm{~N} \mathrm{ov}$. & 5 to $12 \mathrm{~N} \mathrm{ov}$. \\
\hline NA-59907 & PRO & $30 \mathrm{Oct}$. to $20 \mathrm{~N} \mathrm{ov}$. & $20 \mathrm{~N}$ ov. to $3 \mathrm{D} \mathrm{ec}$. \\
\hline NA-60068 & PRO & $27 \mathrm{Oct}$. to $13 \mathrm{Nov}$. & 13 to $26 \mathrm{Nov}$. \\
\hline N A-61016 & RP & $30 \mathrm{Oct}$. to $13 \mathrm{~N} \mathrm{ov}$. & 13 to $23 \mathrm{~N} \mathrm{ov}$. \\
\hline Alapaha & YO & $9 \mathrm{Nov}$. to $6 \mathrm{Dec}$. & 6 to $20 \mathrm{D} \mathrm{ec}$. \\
\hline Autumn Blaze & RPO & $27 \mathrm{Oct}$. to $9 \mathrm{~N} \mathrm{ov}$. & 9 to $18 \mathrm{~N} \mathrm{ov}$. \\
\hline Autumn Flame & OYR & 300 ct. to $17 \mathrm{Nov}$. & 17 to $26 \mathrm{Nov}$. \\
\hline Edna $D$ avis & RPO & 200 ct. to $11 \mathrm{~N} \mathrm{ov}$. & 11 to $22 \mathrm{Nov}$. \\
\hline O ctober G lory & RPO & $27 \mathrm{Oct}$. to $23 \mathrm{~N} \mathrm{ov}$. & $23 \mathrm{~N}$ ov. to $3 \mathrm{D} \mathrm{ec}$. \\
\hline Red Sunset & RPO & $27 \mathrm{Oct}$ to $19 \mathrm{~N} \mathrm{ov}$. & 19 to $25 \mathrm{~N}$ ov. \\
\hline $\mathrm{OH}-1$ & RO & $9 \mathrm{Nov}$. to $5 \mathrm{Dec}$. & 5 to $7 \mathrm{Dec}$. \\
\hline
\end{tabular}

${ }^{2}$ Cultivar names corresponding to NA accession numbers if available are NA-56021 ('Cumberland'); NA-59905 ('Somerset'); NA-59906 ('Sun Valley'); NA-59907 ('Brandywine'); and N A-57772 ('Red Rocket').

${ }^{y}$ Color notation as follows: $B=$ brown, $O=$ orange, $P=$ purple, $R=$ red, $Y=$ yellow (primary color listed first).

ies. Different data collection procedures in different studies occasionally create difficulty in making direct crossstudy comparisons. In addition to recent reports from the U.S. N ational
Arbo retum (D ix, 1997; T ownsend and D ouglass, 1998), results of theseevaluations indicate that several of the $\mathrm{N} \mathrm{a}$ tional Arboretum selections demonstrate suitable growth and autumn color performance in the coastal plain of Georgia. N oteworthy exceptions would be the poor performance of N A-57772 ('Red Rocket') and NA56024 (Tables 1-2). 
Fall color patterns were evaluated annually, however, only 1995, 1996, and 1997 results are presented in this report (Figs. 1-3). The data collected during these years was on well established trees and offers a true picture of the fall color performance that might beexpected for those cultivarsin so uthern Georgia. For commercially availablecultivars, the most dependable fall color (Figs. 1-3) has been evident in 'O ctober Glory' ${ }^{\circledR}$, although the development of color is not nearly as good as it is in the Atlanta, Georgia area (J.M. Ruter, personal observation). Two new selections from the $\mathrm{N}$ ational Arboretum, 'Somerset' and 'Brandywine', showed excellent purple/ red fall color in Tifton. Fall color was generally poor for 'A utumn Flame' and 'Red Sunset' $T M$ in Tifton.

Leaf hoppers (Empoasca fabae $\mathrm{H}$ arris) and the maple tip borer (EpisimustyriusH einrich) (Solomon, 1995) are maple insect pests statewide. $D$ amagefrom the mapletip borer is usually evident by the second week of $\mathrm{M}$ ay in Tifton with the second generation of adultscausing themost damage in J une. All trees in the T ifton trial are attacked annually by the maple tip borer (J .M . Ruter, unpublished data).

T ar spot [R hytisma acerinum (Pers.:Fr.)Fr.] seemed to infect seedling selections from F lorida and G eorgia, but was not a problem on any of the N ational Arboretum or commercially available cultivars at Tifton. Bot canker (Botryosphaeria Ces. \& D eN ot.) was isolated from N A-61016 and several seedlings at $\mathrm{T}$ ifton after very dry summers.

Evaluation trials of this type will prove horticulturally valuable as new introductionsof selected seedlingsfrom nurseries and the $\mathrm{N}$ ational Arboretum are released to industry. O ur trial results gave an indication of expectations of growth and performance following establishment under field or landscape conditions throughout southern Georgia and similar regions of the southeast. As our trees mature, future reports on fall color, branching habits, and scaffold strength will continue to give growers valuable information. The data presented from trials such as these could help growers select faster growing cultivars for production. While faster growing trees can be an important consideration for nursery growers, not all fast growing trees areadapted throughout the so utheastern U.S. Furthermore, while selections such as 'Alapaha' demonstrate excellent growth at Tifton (normally defoliating around the first of $D$ ecember and often flowering by the first week of February), selectionswith consistent red fall color are still needed in U SD A zone 8 since the predominate fall color of 'Alapaha' is yellow (Figs. 1-3). The release of 'Brandywine' and 'Somerset' from the $\mathrm{N}$ ational Arboretum give producersand consumersthe possibility of a reliable red-orangepurplefall color palette in U SD A zone 8. Pleaseuse sound horticultural judgement when interpreting the data presented in this and other related studies.

\section{Literature cited}

American Horticultural Society. 1997. Plant heat-zone map. Amer. H ort. Soc., Alexandria, $\mathrm{Va}$.

Bachtel, K.R. 1989. A fortunate blend. Amer. N urs. 169(8):40-43, 46, 48, 5055.

Dix, R.L. 1997. $\mathrm{N}$ ew releases from the U .S. N ational Arboretum. Combined Proc. Intl. Plant Prop. Soc. 47:460-463.

Downs, R.J. and H.A. Borthwick. 1956. Effects of photoperiod on growth of trees. Bot. Gaz. 117:310-326.

Fare, D.C., C.H. Gilliam, and H.G. Ponder. 1990. A cer rubrum cultivars for the south. J. Arboricult. 16:25-29.
Perry, T.O. and C. Wang. 1960. Genetic variation in the winter chilling requirement date of dormancy break for Acer rubrum. Ecology 41:790-794.

Perry, T.O. 1971. Dormancy of trees in winter. Science 171:29-36.

Ruter, J.M . 1996. M apleevaluation project at the Coastal Plain Experiment Station, Tifton. Ga. Green Ind. Assn. J. 7(2):2526.

Santamour, F.S., Jr. 1993. Freeman maple-Illusion and truth. J. Arboricult. 19:195-199.

Santamour, Jr., F.S. and A.J. M cArdle. 1982. Checklist of cultivated maples I. A cer rubrum L. J. Arboricult. 8:110-112.

Sibley, J.L., D .J. Eakes, C.H . Gilliam, G.J . Keever, and W.A.D ozier, Jr. 1995. G rowth and fall color of red maple selections in the southeastern U nited States. J. Environ. Hort. 13:51-53.

Solomon, J.D. 1995. Guide to insect borers in N orth American broadleaf trees and shrubs. A gr. H dbk. 706. U SD A For. Serv., Washington, D.C.

T ownsend, A.M . 1977. Characteristics of red maple progenies from different geographic areas. J. Amer. Soc. Hort. Sci. 102:461-466.

Townsend, A.M . and L.W. D ouglass. 1998. E valuation of varioustraits of 40 selections and cultivars of red maple and freeman maple growing in $\mathrm{M}$ aryland. J. Environ. Hort. 16:189-194.

U.S. D epartment of Agriculture. 1990. U SD A plant hardiness zone map. U SDA $\mathrm{M}$ isc. Publ.

Williams, J.D., D.C. Fare, C.H. Gilliam, G.J. Keever, H.G. Ponder, and J.T. O wen. 1993. Shade trees for the southeastern U nited States. Ala. Agr. Expt. Sta., Auburn.

Witte, W.T., R. Sauve, and P.C. Flanagan. 1997. U pdate on maple evaluations at TSU - N CRS. Proc. S. N ursery Assn. Res. Conf. 42:446-452. 